\title{
Management of breakthrough pain in children with cancer
}

This article was published in the following Dove Press journal:

Journal of Pain Research

7 March 2014

Number of times this article has been viewed

\author{
Stefan J Friedrichsdorf ${ }^{1,2}$ \\ Andrea Postier' \\ 'Department of Pain Medicine, \\ Palliative Care and Integrative \\ Medicine, Children's Hospitals and \\ Clinics of Minnesota, ${ }^{2}$ University \\ of Minnesota Medical School, \\ Minneapolis, MN, USA
}

\begin{abstract}
Breakthrough pain in children with cancer is an exacerbation of severe pain that occurs over a background of otherwise controlled pain. There are no randomized controlled trials in the management of breakthrough pain in children with cancer, and limited data and considerable experience indicate that breakthrough pain in this pediatric patient group is common, underassessed, and undertreated. An ideal therapeutic agent would be rapid in onset, have a relatively short duration, and would be easy to administer. A less effective pharmacologic strategy would be increasing a patient's dose of scheduled opioids, because this may increase the risk of oversedation. The most common and effective strategy seems to be multimodal analgesia that includes an immediate-release opioid (eg, morphine, fentanyl, hydromorphone, or diamorphine) administered intravenously by a patient-controlled analgesia pump, ensuring an onset of analgesic action within minutes. Intranasal fentanyl (or hydromorphone) may be an alternative, but no pediatric data have been published yet for commercially available fentanyl transmucosal application systems (ie, sublingual tablets/spray, buccal lozenge/tablet/film, and nasal spray), and these products cannot yet be recommended for use with children with cancer and breakthrough pain. The aim of this paper was to emphasize the dearth of available information on treatment of breakthrough pain in pediatric cancer patients, to describe the treatment protocols we currently recommend based on clinical experience, and to suggest future research on this very important and under-researched topic.
\end{abstract}

Keywords: pediatric, cancer, breakthrough pain, opioid, adjuvant analgesia, integrative medicine

\section{Introduction}

Children with cancer-related pain experience fluctuations in pain intensity. When exacerbations of medium-to-severe pain occur over the background of otherwise-controlled pain, it is commonly described as breakthrough pain. Subgroups of breakthrough pain include incidental pain, which is typically induced by a child's movements; endof-dose failure, requiring adjustment of the dosing regimen; and spontaneous pain, where no obvious pathology is apparent. Breakthrough pain frequently occurs in conjunction with background pain that is well managed by analgesia (typically opioid medications plus adjuvants) in conjunction with integrative, nonpharmacological therapies. Breakthrough pain in adults is prevalent, with up to two-thirds of cancer patients affected. ${ }^{1-3}$ A study of the characteristics and impact of breakthrough pain in adult patients with cancer pain demonstrated that breakthrough pain independently contributed to impaired functioning and psychological distress. ${ }^{2}$ Breakthrough pain was also associated with negative mood and the study confirmed that it is a prevalent and heterogeneous phenomenon. The likelihood of an adequate analgesic response to opioid therapy is diminished by the presence of breakthrough pain.,
Correspondence: Stefan J Friedrichsdorf Department of Pain Medicine, Palliative Care and Integrative Medicine, Children's Hospitals and Clinics of Minnesota, 2525 Chicago Avenue, Minneapolis, MN 55404, USA

$\mathrm{Tel}+\mathrm{I} 6128136450$

Fax +16128137199

Email stefan.friedrichsdorf@childrensmn. org 
The inferred pathophysiology of breakthrough pain may be categorized as somatic, visceral, or neuropathic. ${ }^{6}$ Somatic pain is usually localized, and is often referred to as "aching"; examples include association with primary or metastatic bone disease or postsurgical incisional pain. Visceral pain is often poorly localized, and may occur as a result of infiltration, compression, distention, or stretching of thoracic and abdominal viscera by a tumor. This pain is described as "deep" and "pressure"; an example is pain associated with tumor of the liver. Neuropathic pain is related to an injured neural structure, and frequently results in painful dysesthesia (ie, "burning pain").

Despite the clinical importance of breakthrough pain, there are few data in children with cancer, and routine clinical practice does not include the recognition, evaluation, and treatment of breakthrough pain in these children. There are no published randomized controlled trials in the management of pediatric cancer breakthrough pain and only one pediatric study in the assessment of this type of pain. This study involved patient assessment with a structured interview tool (Breakthrough Pain Questionnaire for Children) that was designed to characterize breakthrough pain in children. ${ }^{7}$ Results revealed that $57 \%$ of the children with cancer had experienced one or more episodes of breakthrough pain during the preceding 24 hours, with episodes lasting seconds to minutes, occurring three to four times per day, and most commonly characterized as "sharp" and "shooting" by the children. Younger children (7-12 years of age) had a significantly higher risk of experiencing breakthrough pain compared to teenagers, and the most effective treatment of an episode of breakthrough pain was a patientcontrolled analgesia (PCA) opioid bolus dose. ${ }^{7}$ A Swedish study of children with cancer receiving opioids for pain management demonstrated that major tumor surgery causes more episodes of breakthrough pain than tumor-associated pain or pain caused by neoplastic drug side effects. ${ }^{8}$

There is a scarcity of data contributing to the evidence base supporting treating cancer breakthrough pain in children. In a study of 2,278 adult cancer patients, 58\% reported breakthrough pain, which contributed in part to reaching consensus on an international cancer pain classification system, with breakthrough pain and psychological distress confirmed as key variables of a future classification system. ${ }^{9}$ Although highly variable, pediatric breakthrough pain in our clinical experience is typically rapid in onset, moderate to severe in intensity, and relatively short in duration. Because of the acute characteristics of breakthrough pain, oral opioids are usually not an ideal choice of analgesia. Optimizing background (scheduled) analgesia in patients with breakthrough pain is the first step in avoiding breakthrough pain in children with acute cancer pain. Therefore, we begin by reviewing key principles of acute cancer background pain management, followed by a review of breakthrough pain management.

\section{Management of acute background pain}

The majority of children with cancer experience mediumto-severe pain, which may be disease- or treatment- (including procedure/intervention)-related somatic, visceral, neuropathic, and/or spiritual pain. Reasons for children with acute cancer pain to have worsening pain may include disease progression or infection at the tumor site, development of tolerance, drug interactions, decreasing renal function with accumulation of nociceptive metabolites (eg, morphine3-glucuronide or hydromorphone-3-glucuronide), and/or somatization and psychological distress.

Data suggest that applying the following World Health Organization (WHO) principles of pain management results in good pain relief for the majority of children with cancer, ${ }^{10,11}$ including those with mucositis pain:

1. Using a two-step strategy ("by the analgesic ladder")

2. Dosing at regular intervals ("by the clock")

3. Using the appropriate route of administration ("by the appropriate route")

4. Adapting treatment to the individual child ("with the child").

\section{Using a two-step strategy \\ ("by the analgesic ladder")}

Pain severity dictates the choice of analgesic. Mild acute cancer pain may be treated with acetaminophen (paracetamol) and/or ibuprofen if there are no contraindications. Mediumto-severe acute cancer pain requires strong pain medication, such as opioids (eg, morphine, fentanyl, hydromorphone, oxycodone, or methadone) (see Table 1). These same concepts would not hold true for severe chronic pain, however. In children with such conditions as functional abdominal pain, tension-type headaches/migraines, chronic musculoskeletal pain/juvenile fibromyalgia syndrome, and pain "beyond the expected time of healing" (eg, daily chronic pain weeks or months after a hemoglobin sickle-cell anemia-induced vasoocclusive crisis), opioids would actually be contraindicated and usually should not be administered. ${ }^{12}$

\section{Dosing at regular intervals ("by the clock")}

Regular scheduling ensures a steady blood level, reducing the peaks and troughs of "as needed" (pro re nata [PRN]) dosing. Dosing that is "PRN only" (without scheduled analgesia) 
Table I Opioid analgesics: usual starting doses (calculated rescue [breakthrough] dose for morphine, hydromorphone, and oxycodone: $10 \%$ of 24 -hour opioid dose to be given every $\mathrm{I}-2$ hours as needed)

\begin{tabular}{|c|c|c|c|c|c|}
\hline $\begin{array}{l}\text { Drug (route of } \\
\text { administration) }\end{array}$ & $\begin{array}{l}\text { Equianalgesic } \\
\text { dose (parenteral) }\end{array}$ & Starting dose (IV) & $\begin{array}{l}\text { IV:PO } \\
\text { ratio }\end{array}$ & $\begin{array}{l}\text { Starting dose PO } \\
\text { (transdermal) }\end{array}$ & $\begin{array}{l}\text { Starting dose } \\
\text { controlled release }^{a}\end{array}$ \\
\hline $\begin{array}{l}\text { Morphine } \\
\text { (PO, SL, IV, SC, PR) }\end{array}$ & $10 \mathrm{mg}$ & $\begin{array}{l}\text { Bolus dose: } 50-100 \mu g / k g \text { every } \\
2-4 \text { hours } \\
\text { Continuous infusion: } 10-30 \mu g / k g / \text { hour }\end{array}$ & $1: 3$ & $\begin{array}{l}0.15-0.3 \mathrm{mg} / \mathrm{kg} \text { every } \\
4 \text { hours }\end{array}$ & $\begin{array}{l}0.45-0.9 \mathrm{mg} \text { every } \\
12 \text { hours }\end{array}$ \\
\hline $\begin{array}{l}\text { Fentanyl (IV, SC, SL, } \\
\text { transdermal, buccal) }\end{array}$ & $100-250 \mu \mathrm{g}$ & $\begin{array}{l}\text { Bolus dose: I-3 } \mu \mathrm{g} / \mathrm{kg} \text { (slowly over } \\
3-5 \text { minutes; fast bolus may cause } \\
\text { thorax rigidity) } \\
\text { Continuous infusion: } \mathrm{I}-2 \mu \mathrm{g} / \mathrm{kg} / \mathrm{hour}\end{array}$ & $\begin{array}{l}\mathrm{I}: \mathrm{I} \text { (IV to } \\
\text { transdermal) }\end{array}$ & $\begin{array}{l}12 \mu \mathrm{g} / \text { hour patch (must } \\
\text { be the equivalent of } \\
\text { at least } 30 \mathrm{mg} \text { oral } \\
\text { morphine/ } 24 \text { hours } \\
\text { before switching patch) }\end{array}$ & NA \\
\hline $\begin{array}{l}\text { Hydromorphone } \\
\text { (PO, SL, IV, SC, PR) }\end{array}$ & $1.5 \mathrm{mg}$ & $\begin{array}{l}\text { Bolus dose: } 15-20 \mu g / k g \text { every } 4 \text { hours } \\
\text { Continuous infusion: } 5 \mu \mathrm{g} / \mathrm{kg} / \text { hour }\end{array}$ & $\mathrm{I}: 5$ & $\begin{array}{l}60 \mu g / k g \text { every } \\
3-4 \text { hours }\end{array}$ & $\begin{array}{l}\text { I } 80 \mu \mathrm{g} / \mathrm{kg} \text { every } \\
\text { I } 2 \text { hours; currently } \\
\text { not available in US }\end{array}$ \\
\hline $\begin{array}{l}\text { Oxycodone } \\
\text { (PO, SL, PR) }\end{array}$ & $5-10 \mathrm{mg}$ & NA & NA & $\begin{array}{l}0.1-0.2 \mathrm{mg} / \mathrm{kg} \text { every } \\
4-6 \text { hours }\end{array}$ & $\begin{array}{l}0.3-0.9 \mathrm{mg} / \mathrm{kg} \text { every } \\
12 \text { hours }\end{array}$ \\
\hline Tramadol (PO, PR) & $100 \mathrm{mg}$ & $\begin{array}{l}\text { IV not available in US } \\
\text { Bolus dose: I mg/kg every } 3-4 \text { hours } \\
\text { Continuous infusion: } 0.25 \mathrm{mg} / \mathrm{kg} / \mathrm{hour}\end{array}$ & $\mathrm{I}: \mathrm{I}$ & $\begin{array}{l}\mathrm{I}-2 \mathrm{mg} / \mathrm{kg} \text { every } \\
3-4 \mathrm{hours} \text {, maximum of } \\
8 \mathrm{mg} / \mathrm{kg} / \text { day }(>50 \mathrm{~kg}: \\
\text { maximum of } 400 \mathrm{mg} / \text { day })\end{array}$ & $\begin{array}{l}2-4 \mathrm{mg} / \mathrm{kg} \text { every } \\
12 \text { hours }\end{array}$ \\
\hline
\end{tabular}

Note: aDoses are for children $>6$ months of age, and are capped at $50 \mathrm{~kg}$ body weight.

Abbreviations: IV, intravenous; PO, per os (by mouth); SL, sublingual; SC, subcutaneous; PR, per rectum; NA, not applicable.

may take several hours and require higher opioid doses to relieve pain; it may result in cycles of undermedication and associated pain, alternating with periods of overmedication and possible drug toxicity. ${ }^{13}$ Commonly used opioid regimens include immediate-release oral morphine every 4 hours, or controlled-release morphine twice daily, plus a PRN dose of $10 \%$ of the 24 -hour morphine requirement as an hourly fastrelease breakthrough pain medication (the same holds true for both medications). Most pediatric medical institutions in developed countries administer opioids to children with cancer using a continuous infusion of one opioid (typically morphine, fentanyl, or hydromorphone; or in the UK, diamorphine) plus a PCA bolus (see Table 2). If a child is too young or unable to push the PCA button, many institutions, including ours, will implement a nurse-controlled analgesia (NCA) bolus policy. In our previous breakthrough cancer pain study, none of the children had uncontrolled background pain after 48 hours of scheduled opioids. ${ }^{7}$

Due to legitimate concerns about the side-effect profile of long-term opioid administration, current multimodal analgesia is geared towards opioid-sparing analgesia. In our experience, it includes not only the "simple" WHO step 1 medications (eg, acetaminophen, nonsteroidal antiinflammatory drugs [NSAIDs]) but also the possible addition of adjuvant analgesia (see Table 3). Due to their potential side effects, acetaminophen and NSAIDs obviously need to be used with caution and careful monitoring in this patient group, and may even be contraindicated in individual patients. Adjuvant analgesia may either be indicated to achieve an opioid-sparing effect for acute pain, eg, dexmedetomidine or gabapentin and/or managing a neuropathic or visceral pain component, eg, $\alpha$-agonists (such as dexmedetomidine or clonidine), gabapentinoids (such as gabapentin or pregabalin), tricyclic antidepressants (such as low-dose amitriptyline or nortriptyline), $\mathrm{N}$-methyl-D-aspartate-channel blockers (such as low-dose ketamine), with a strong emphasis on supportive, rehabilitative, and integrative therapies, such as distraction, biofeedback, deep breathing, and self-hypnosis (Figure 1). A detailed review of the use of adjuvant analgesia in children with cancer has been published recently. ${ }^{14}$

Table 2 Usual starting doses for patient- or nurse-controlled analgesia pumps

\begin{tabular}{|c|c|c|c|c|}
\hline & $\begin{array}{l}\text { Continuous infusion } \\
\text { ( } \mu \mathrm{g} / \mathrm{kg} / \mathrm{hour})\end{array}$ & PCA bolus $(\mu g)$ & $\begin{array}{l}\text { Lockout time } \\
\text { (minutes) }\end{array}$ & $\begin{array}{l}\text { Maximum number } \\
\text { of boluses/hour }\end{array}$ \\
\hline Morphine & 20 (maximum 1,000 ) & 20 (maximum 1,000 ) & $5-10$ & $4-6$ \\
\hline Hydromorphone & 3-5 (maximum 250) & 3-5 (maximum 250) & $5-10$ & $4-6$ \\
\hline Fentanyl & I (maximum 50) & I (maximum 50) & 5 & $4-6$ \\
\hline
\end{tabular}

Notes: Doses are for children $>6$ months of age, and are capped at $50 \mathrm{~kg}$ body weight. Dose escalation is usually calculated in $50 \%$ increments, both for continuous and PCA/NCA bolus doses.

Abbreviations: PCA, patient-controlled analgesia; NCA, nurse-controlled analgesia. 
Table 3 Adjuvant analgesia in neuropathic pediatric cancer pain management

\begin{tabular}{|c|c|c|c|c|}
\hline Class & Medication & Dose & $\begin{array}{l}\text { Route of } \\
\text { administration }\end{array}$ & Comments/side effects \\
\hline \multirow[t]{2}{*}{$\begin{array}{l}\text { Tricyclic } \\
\text { antidepressants } \\
\text { (TCAs) }\end{array}$} & Amitriptyline & $\begin{array}{l}\text { Starting dose } 0.1 \mathrm{mg} / \mathrm{kg} \text { QHS, usually } \\
\text { slowly titrated up to } 0.5 \mathrm{mg} / \mathrm{kg} \\
\text { (maximum } \mathrm{I}-2 \mathrm{mg} / \mathrm{kg} \text { ) }\end{array}$ & $\mathrm{PO}$ & $\begin{array}{l}\text { Tertiary amine TCA; stronger } \\
\text { anticholinergic side effects (including } \\
\text { sedation) than nortriptyline }\end{array}$ \\
\hline & Nortriptyline & $\begin{array}{l}\text { Starting dose } 0.1 \mathrm{mg} / \mathrm{kg} \text { QHS, usually } \\
\text { titrated up to } 0.5 \mathrm{mg} / \mathrm{kg} \\
\text { (maximum } 1 \mathrm{mg} / \mathrm{kg} \text { ) }\end{array}$ & $\mathrm{PO}$ & $\begin{array}{l}\text { Secondary amine TCA; anticholinergic } \\
\text { side effects }\end{array}$ \\
\hline \multirow[t]{2}{*}{ Gabapentinoids } & Gabapentin & $\begin{array}{l}\text { Starting dose } 2 \mathrm{mg} / \mathrm{kg} \text { QHS, usually } \\
\text { slowly titrated up to initial target dose } \\
\text { of } 6 \mathrm{mg} / \mathrm{kg} / \text { dose TID (maximum } \\
300 \mathrm{mg} / \text { dose TID). Maximum dose } \\
\text { escalation to } 24 \mathrm{mg} / \mathrm{kg} / \text { dose TID } \\
\text { (maximum } 1,200 \mathrm{mg} / \text { dose TID) }\end{array}$ & $\mathrm{PO}$ & $\begin{array}{l}\text { Slow dose increase required. Side } \\
\text { effects ataxia, nystagmus, myalgia, } \\
\text { hallucination, dizziness, somnolence, } \\
\text { aggressive behaviors, hyperactivity, } \\
\text { thought disorder, peripheral edema }\end{array}$ \\
\hline & Pregabalin & $\begin{array}{l}\text { Starting dose } 0.3 \mathrm{mg} / \mathrm{kg} \text { QHS, usually } \\
\text { slowly titrated up to initial target dose } \\
\text { of } 1.5 \mathrm{mg} / \mathrm{kg} / \text { dose BID (maximum } \\
75 \mathrm{mg} / \text { dose BID). Maximum dose } \\
\text { escalation to } 6 \mathrm{mg} / \mathrm{kg} / \text { dose BID } \\
\text { (maximum } 300 \mathrm{mg} / \text { dose BID) }\end{array}$ & $\mathrm{PO}$ & $\begin{array}{l}\text { Switch from gabapentin if distressing } \\
\text { side effects or inadequate analgesia } \\
\text { Side effects ataxia, nystagmus, myalgia, } \\
\text { hallucinations, dizziness, somnolence, } \\
\text { aggressive behaviors, hyperactivity, } \\
\text { thought disorder, peripheral edema; } \\
\text { associated with weight gain }\end{array}$ \\
\hline $\begin{array}{l}\text { Sodium-channel } \\
\text { blocker/local anesthetic }\end{array}$ & Lidocaine 5\% & $\begin{array}{l}\text { Maximum of four patches (in patients } \\
>50 \mathrm{~kg} \text { ) } 12 \text { hours on } / 12 \text { hours off }\end{array}$ & $\begin{array}{l}\text { Transdermal } \\
\text { patch }\end{array}$ & Not for severe hepatic dysfunction \\
\hline Glucocorticoid & Dexamethasone & $\begin{array}{l}0.1-1.5 \mathrm{mg} / \mathrm{kg} \text { (maximum } 10 \mathrm{mg} \text { ) } \\
\text { starting dose, then } 0.1-0.25 \mathrm{mg} / \mathrm{kg} \\
\times 2 / \text { day (for }<14 \text { days) } \\
\text { (Malignant spinal cord compression } \\
\text { [adult dose]: dexamethasone } \\
16-96 \mathrm{mg} / \text { day or equivalent) }\end{array}$ & PO, IV & Add gastroprotective agent \\
\hline $\begin{array}{l}\text { NMDA-receptor } \\
\text { antagonist }\end{array}$ & $\begin{array}{l}\text { Ketamine (racemic } \\
\text { mixture of } S^{+} / R^{-} \\
\text {enantiomers) }\end{array}$ & $\begin{array}{l}\text { IV } 0.06-0.3 \mathrm{mg} / \mathrm{kg} / \mathrm{hour} \\
\text { PO } 0.2-0.5 \mathrm{mg} / \mathrm{kg} \text { TID-QID and PRN }\end{array}$ & $\begin{array}{l}\mathrm{IV}, \mathrm{PO},(\mathrm{SC}, \mathrm{SL}, \\
\text { intranasal, } \\
\text { spinally) }\end{array}$ & $\begin{array}{l}\text { Typical side effects rare at low dose, } \\
\text { but would require benzodiazepine } \\
\text { administration }\end{array}$ \\
\hline
\end{tabular}

Abbreviations: QHS, quaque hora somni (every night at bedtime); TID, ter in die (three times a day); BID, bis in die (twice a day); QID, quater in die (four times a day); IV, intravenous; PO, per os (by mouth); SL, sublingual; SC, subcutaneous; NMDA, N-methyl-D-aspartate; PRN, pro re nata (as needed).

\section{Using the appropriate route of administration ("by the appropriate route")}

The least invasive route of administration, often chosen by the child, should be used, thus making intramuscular administration obsolete. The oral route (or via nasogastric/ percutaneous endoscopic gastrostomy tube if applicable) is convenient, noninvasive, and usually preferred by children and their care providers. The IV administration of opioids may be feasible, especially when there is central access. PCA/NCA combined with a continuous background analgesic approach often provides excellent pain management. Alternatively, opioid analgesics can be administered subcutaneously in IVequivalent doses. Transdermal fentanyl patches are not usually indicated for acute pain management, due to their long onset time (it may take over 60 hours to reach peak concentrations in children), inability to rapidly titrate drug delivery, and long elimination half-life (up to 24 hours). In pediatric cancer pain, patches can be applied on intact, healthy skin every 48-72 hours, but they cannot be used with opioid-naïve children (ie, $30-60 \mathrm{mg}$ oral morphine per 24 hours) for safe rotation to a fentanyl patch. The smallest patch delivers $12 \mu \mathrm{g}$ /hour. A sufficient immediate-release breakthrough (rescue) opioid should also be provided. Transdermal fentanyl has a role in longerlasting, stable acute pediatric pain. Transmucosal routes (ie, sublingual, buccal, intranasal) offer other options for route of administration, and these are discussed in greater detail.

\section{Adapting treatment to the individual child ("with the child")}

Analgesic treatment should be individualized according to the child's pain and his/her response to treatment. Treatment effectiveness should be frequently assessed and reassessed, and modified as required. Some children may require extremely high doses of opioids to control severe cancer pain. As mentioned previously, adjuvant drugs may be appropriate in the pain management of an individual child, as part of a multimodal approach.

At analgesic dosing, sedation is not expected. It is a commonly believed myth that patients, parents, or clinicians must choose between a child being either in pain or being oversedated. Oversedation with multimodal analgesia can be 


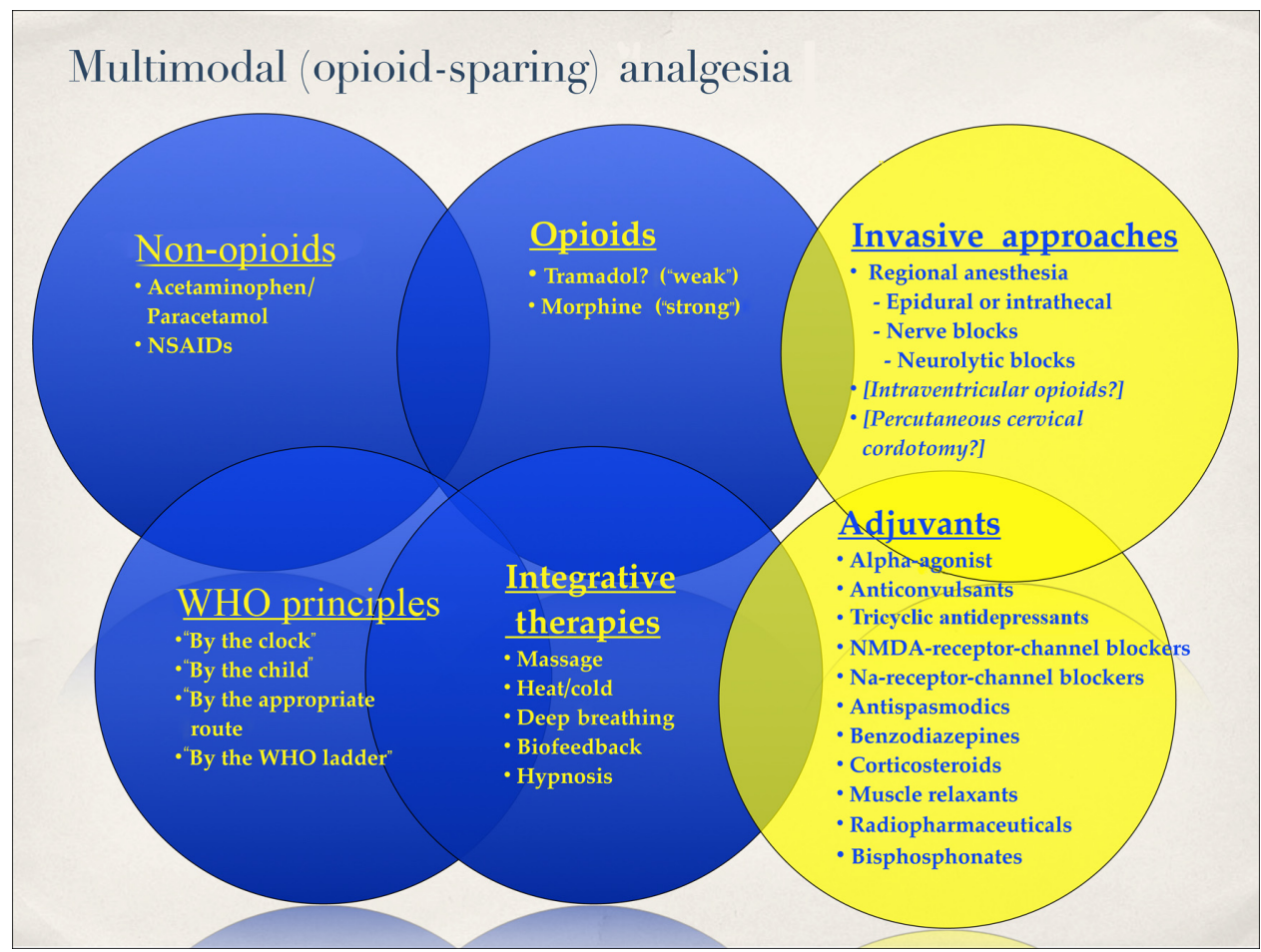

Figure I Managing children in acute cancer pain: multimodal "opioid-sparing” analgesia.

Notes: Blue circles show the standard approach; yellow circles show an advanced management approach in select cases.

Abbreviations: NSAIDs, nonsteroidal anti-inflammatory drugs; WHO, World Health Organization; NMDA, N-methyl-D-aspartate.

avoided, including in cases where opioid rotation at equianalgesic doses is necessary due to opioid-induced side effects. The effective analgesic opioid dose is what relieves pain, and different children may respond differently to the same dose. The effective dose must be adjusted to the child's needs, which involves assessing the child's response frequently using validated pediatric pain scales and watching closely for opioid-induced side effects and toxicity.

\section{Management of breakthrough pain}

Breakthrough pain includes such entities as: 1) incidental pain, which is typically induced by a child's movements (which may require adjustment of the dosing regimen and/or an analgesic dose prior to movement such as during physical therapy, going to the bathroom etc), 2) end-of-dose failure (requiring adjustment of the dosing regimen, such as increasing the dose and/ or decreasing the dosing interval), and 3) spontaneous pain, where no obvious pathology is apparent. Breakthrough pain in our experience frequently occurs in children with cancer in conjunction with background pain that is usually well managed by multimodal analgesia.

\section{"Classic" routes of opioid administration: intravenous, oral, and rectal}

Calculating a "breakthrough" (or "rescue" or PRN) opioid dose in pediatric cancer pain usually involves administering
$10 \%$ of the total daily dose (in adults, the WHO recommends up to a sixth of the total daily dose) for the immediateacting opioids morphine, hydromorphone, oxycodone and diamorphine. Fentanyl, due to its short half-life, would be calculated differently.

\section{Example I (oral)}

A 10-year-old $(29 \mathrm{~kg}$ ) patient receiving immediate-release oxycodone $10 \mathrm{mg}$ orally every 6 hours would receive a total of $40 \mathrm{mg}$ orally per 24 hours. Ten percent of the total daily dose would be $4 \mathrm{mg}$ to be administered every $1-2$ hours PRN for breakthrough pain.

\section{Example 2 (IV)}

A 1-year-old patient is receiving hydromorphone $0.3 \mathrm{mg}$ IV every 4 hours, which translates into $1.8 \mathrm{mg}$ IV per 24 hours. Ten percent of the total daily dose would be $0.18 \mathrm{mg}$ IV hydromorphone to be administered every 1-2 hours PRN for breakthrough pain.

\section{Patient- and nurse-controlled analgesia-delivery systems}

In most pediatric cancer centers, the standard delivery modality for IV opioid administration for acute cancer pain is the PCA pump, which combines a continuous opioid infusion plus PCA administration. As mentioned previously, if the 
child is too young, or unable to push the PCA button him or herself, NCA is available instead. A recent meta-analysis reported that the combination of a continuous (or background) infusion with a demand (or PCA bolus) dose for IV PCA is not associated with a higher incidence of respiratory events than PCA bolus alone in pediatric patients, which is in contrast to adults. ${ }^{15}$

\section{Example 3 (PCA)}

A 3-year-old patient $(18 \mathrm{~kg})$ is receiving fentanyl by continuous infusion at a rate of $25 \mu \mathrm{g} /$ hour. A PCA bolus dose usually equals the hourly dose, in this case $25 \mu \mathrm{g}$. A lockout time (ie, time frame in which the pump will not deliver an additional bolus dose) depends on the clinical scenario, such as 5-10 minutes with a maximum of 4-6 boluses (again, depending on the clinical scenario) allowed per hour. The same principles would apply for IV morphine and IV hydromorphone.

Our study and clinical experience combined has shown that PCA opioid boluses are the most effective means of managing breakthrough cancer pain for pediatric inpatients, possibly due to their short onset of action and the degree of control a child gains by having access to the PCA device. ${ }^{7}$

\section{Novel routes of administration}

Intranasal fentanyl is an effective and commonly used short-acting analgesic, most commonly used in our pediatric emergency rooms. The nasal mucosa is richly vascularized, and fenestrated epithelium drains by way of the facial and sphenopalatine veins, thereby avoiding first-pass metabolism. When IV fentanyl (off-label) is drawn up into a syringe and administered intranasally by using a mucosal atomization device, its analgesic and pharmacokinetic profile appears similar to IV administration in children, with a bioavailability of $70 \%-80 \% .^{16-18}$

There are currently six different fentanyl transmucosal application systems approved for breakthrough cancer pain in adults (not for children) by the US Food and Drug Administration: a sublingual tablet (Abstral ${ }^{\circledR}$; Galena Biopharma, Portland, OR, USA), a sublingual spray (Subsys $^{\circledR}$; INSYS Therapeutics Inc., Chandler, AZ, USA), lozenges (Actiq ${ }^{\circledR}$; Teva Pharmaceutical Industries, Petah Tikva, Israel), buccal tablets (Fentora ${ }^{\circledR}$; Teva), buccal film (Onsolis $^{\circledR}$; BioDelivery Sciences International, Raleigh, NC, USA), and a nasal spray (Lazanda ${ }^{\circledR}$; Depomed, Inc., Newark, CA, USA/Instanty $1^{\circledR}$; Takeda Pharmaceutical, Osaka, Japan). Each costs approximately US\$17-\$120 per administration.
There are no pediatric randomized controlled trials for any of these commercially available fentanyl transmucosal delivery systems, and even the adult literature has recently received a rather sober critique, with the published studies being sponsored by the manufacturers, raising concern for bias. ${ }^{19}$ The chosen criteria to define analgesic response varies between studies, making comparison across studies rather difficult. In addition, some approaches taken in the studies do not reflect usual clinical practice. ${ }^{20}$ Therefore, we do not recommend administering transmucosal fentanyl for breakthrough pain management in children at this time.

\section{Conclusion}

Exacerbations of severe pain that occur on a background of otherwise controlled pain occur in a significant number of children with cancer. The ideal therapeutic agent should be rapid in onset, have a relatively short duration of action, and be easy to administer. Increasing the dose of scheduled opioids is not suggested, as this may increase the risk of oversedation. Potentially effective strategies seem to include providing multimodal opioid-sparing analgesia and an immediate-release opioid (eg, morphine, fentanyl, hydromorphone, or diamorphine) administered by a route that ensures an analgesic onset of action within minutes. In our clinical experience, the most commonly used effective strategy is IV administration via a PCA pump. Intranasal fentanyl (or hydromorphone) appears to be an alternative. Commercially available fentanyl transmucosal application systems are promising in children, since they involve a route of administration that is commonly preferred by children. However, they cannot be recommended for children at this time, because there are no pediatric data published yet, and the delivery units are usually only available in doses too high for pediatric use (ie, $>100 \mu \mathrm{g}$ fentanyl).

\section{Disclosure}

The authors report no conflicts of interest in this work.

\section{References}

1. Portenoy RK, Hagen NA. Breakthrough pain: definition, prevalence and characteristics. Pain. 1990;41:273-281.

2. Portenoy RK, Payne D, Jacobsen P. Breakthrough pain: characteristics and impact in patients with cancer pain. Pain. 1999;81:129-134.

3. Zeppetella G, O'Doherty CA, Collins S. Prevalence and characteristics of breakthrough pain in cancer patients admitted to a hospice. $J$ Pain Symptom Manage. 2000;20:87-92.

4. Mercadante S, Maddaloni S, Roccella S, Salvaggio L. Predictive factors in advanced cancer pain treated only by analgesics. Pain. 1992;50: $151-155$.

5. Bruera E, Schoeller T, Wenk R, et al. A prospective multicenter assessment of the Edmonton staging system for cancer pain. $J$ Pain Symptom Manage. 1995;10:348-355. 
6. Collins JJ, Weisman SJ. Management of pain in childhood cancer. In: Schechter NL, Berde CB, Yaster M, editors. Pain in Infants, Children, and Adolescents. Philadelphia: Lippincott, Williams \& Wilkins; 2003:517-538.

7. Friedrichsdorf S, Finney D, Bergin M, Stevens M, Collins J. Breakthrough pain in children with cancer. J Pain Symptom Manage. 2007;34:209-216.

8. Flogegård H, Ljungman G. Characteristics and adequacy of intravenous morphine infusions in children in a paediatric oncology setting. Med Pediatr Oncol. 2003;40:233-238.

9. Knudsen AK, Brunelli C, S Kaasa S, et al. Which variables are associated with pain intensity and treatment response in advanced cancer patients? Implications for a future classification system for cancer pain. Eur J Pain. 2011;15:320-327.

10. World Health Organization. Cancer Pain Relief and Palliative Care in Children. Geneva: WHO; 1998.

11. World Health Organization. Principles of Acute Pain Management for Children. Geneva: WHO; 2012. Available from: http://whqlibdoc. who.int/publications/2012/9789241548120_Guidelines.pdf. Accessed May 15, 2013.

12. Friedrichsdorf S, Kuttner L, Karl H. Pharmacological methods to relieve pain. In: Kuttner L, editor. A Child in Pain: What Health Professionals Can Do to Help. Carmarthen, UK: Crown House Publishing; 2010:221-264.

13. American Pain Society. Principles of Analgesic Use in the Treatment of Acute Pain and Cancer Pain. 6th ed. Chicago: APS; 2008.
14. Friedrichsdorf S, Postier Nugent A. Management of neuropathic pain in children with cancer. Curr Opin Support Palliat Care. 2013;7: $131-138$.

15. George JA, Lin EE, Hanna MN, et al. The effect of intravenous opioid patient-controlled analgesia with and without background infusion on respiratory depression: a meta-analysis. J Opioid Manag. 2010;6:47-54

16. Borland ML, Jacobs I, Geelhoed G. Intranasal fentanyl reduces acute pain in children in the emergency department: a safety and efficacy study. Emerg Med (Fremantle). 2002;14:275-280.

17. Manjushree R, Lahiri A, Ghosh BR, Laha A, Handa K. Intranasal fentanyl provides adequate postoperative analgesia in pediatric patients. Can J Anaesth. 2002;49:190-193.

18. Borland ML, Bergesio R, Pascoe EM, Turner S, Woodger S. Intranasal fentanyl is an equivalent analgesic to oral morphine in paediatric burns patients for dressing changes: a randomised double blind crossover study. Burns. 2005;31:831-837.

19. Nalamacu S, Rauck R, Dilaha L, Parikh N. Lack of correlation between the dose of fentanyl sublingual spray for breakthrough cancer pain and the dose of around-the-clock opioid for persistent pain. J Pain. 2013;14:S74.

20. Twycross R, Prommer EE, Mihalyo M, Wilcock A. Fentanyl (transmucosal). J Pain Symptom Manage. 2012;44:131-149.
Journal of Pain Research

\section{Publish your work in this journal}

The Journal of Pain Research is an international, peer-reviewed, open access, online journal that welcomes laboratory and clinical findings in the fields of pain research and the prevention and management of pain. Original research, reviews, symposium reports, hypothesis formation and commentaries are all considered for publication.

\section{Dovepress}

The manuscript management system is completely online and includes a very quick and fair peer-review system, which is all easy to use. Visit http://www.dovepress.com/testimonials.php to read real quotes from published authors. 